\title{
Strategic Management System of the Territory as a Factor of Increasing Its Competitiveness Level in Financial Organizations
}

\author{
Andrey A. Vorobyev ${ }^{1}$, Irina S. Glebova ${ }^{1} \&$ Liliya V. Khafizova ${ }^{1}$ \\ ${ }^{1}$ Institute of Management, Economics and Finance, Kazan Federal University, Kazan, Russia \\ Correspondence: Andrey A. Vorobyev, Senior Lecturer, Institute of Management, Economics and Finance, Kazan \\ Federal University, Kazan, Russia. Tel: 7-917-867-9450.
}

Received: August 30, 2020

Accepted: October 1, 2020

Online Published: November 30, 2020

doi:10.5430/ijfr.v11n6p219

URL: https://doi.org/10.5430/ijfr.v11n6p219

\begin{abstract}
This paper proposes a methodology for assessing the development level of the strategic management system and the competitiveness level in financial organizations. This methodology served the basis for an analysis of regions and federal cities the Russian Federation. A correlation analysis is also carried out to define the dependence of the constituent entity's competitiveness on the development of the strategic management system that resulted in the proposition of comprehensive solutions.
\end{abstract}

Keywords: strategic management, competitiveness, socio-economic development, correlation analysis, cumulative competitiveness index

\section{Introduction}

Improving the strategic management system of the territory in order to increase its effectiveness is the highest priority policy goal of any state. A new emerging trend throughout the world predetermines the success of the socio-economic development of the constituent territory as well as strengthens its position on the global stage. Similar development prospects determined the adoption of the strategic management system in Russia, which is expressed in the Federal Law No. 172 "On Strategic Planning in the Russian Federation" dated 06/28/2014. The passing of this regulatory act presupposes the creation of a strategic management system of the country's development, which should reflect on its key indicators and on strengthening its competitiveness in the world. Based on this, a hypothesis was suggested that there is a relationship between the development of the strategic management system and the competitiveness level of the regions and federal cities of the Russian Federation.

The system of strategic management of the territory is the most important component of the competitiveness of the region and the country as a whole, which is why many authors, such as: Tazhitdinov I.A. (Tazhitdinov, 2013), Prudskiy V.G., Demin G.A.( Prudskiy et al., 2017), Krasniqi I., Statovci B. (Krasniqi \& Statovci, 2019) pay close attention to this area. A proper study of the strategic management system of the territory is impossible without the study of various aspects. So, for example, Petrova Y.A., Kalinina V.V., Shevandrin A.V. (Petrova et al., 2014), Krasniqi I. (Krasniqi, 2019) defines several interpretations of the concept of strategic management of the territory and highlights main elements of this system. The theoretical aspects of the competitiveness of the territory are studied in the works of such authors as Loginov M.P., Noeva E.E. (Loginov et al., 2018), Glebova I.S., Vorobyev A.A. (Glebova et al., 2015), Tzeremes N.G., Matousek R. (Tzeremes et al., 2018).

The main problem is that there is no consensus in determining the main elements of the strategic management system of the territory, which form the basis of the competitiveness of the region or the country as a whole. Lack of awareness in the study of this category, according to Alexa D., Cismas L. M. (Alexa, 2019), Capello R., Cerisola S.

(Capello \& Cerisola, 2019) inhibits the possibility of intensive development of the territory.

\section{Methods}

This research was performed in various stages. At the initial stage, the Russian Federation's strategic management system in the regions and federal cities was compared. The outcome of this stage is a composite cumulative index of the "Regulatory legal acts" block. Thi block consists of evaluating if the research objects have primary strategic documents, including development strategy, a socio-economic development program, and a competitive development program. These assessments require (ranging) the entities according to whether one or another element of the strategic 
management system is available.

At the second stage, the competitiveness level of subjects was assessed which also involves the calculation of the final composite cumulative index of the competitiveness level. The cumulative level of regional competitiveness is a relative indicator, and therefore should not depend on the size of the territory or the population of the region. Therefore, all the particular signs of competitiveness are included in the calculation of cumulative (summary) values with units of measure expressed in relative values - per capita, volume, share. This final indicator consists of 3 blocks. The first block - "General indicators" - includes indicators characterizing the socio-economic situation of the constituent territory. The second block - "Infrastructure development indicators", enables to assess the level of transport infrastructure, the state of fixed assets and telephone communications. The third block is "Indicators of innovative potential", which shows the development level of innovative production. Based on the analytic hierarchy process, each block is assigned a weighting factor. The final composite cumulative index is calculated by Formula 1.

$$
\mathrm{R}_{\mathrm{i}}=\frac{\sum \mathbf{k j} \cdot \mathbf{P i}}{\mathbf{n}}
$$

Where $R_{i}$ is the composite cumulative index of the subject's competitiveness level in the i-period of time;

$\mathrm{P}_{\mathrm{i}}$ is the composite index of the block in the i-period of time;

$\mathrm{k}_{\mathrm{j}}$ is the weighting factor of the $\mathrm{j}$-th block;

$\mathrm{n}$ is the number of blocks.

The third stage involves testing the hypothesis by means of correlation analysis and applying the results of this analysis to the correlation field. Correlation analysis reflects the relationship between two variables based on the resulting correlation coefficient.

Initially, the results of the cumulative indexes of the strategic management system and the competitiveness of the subject were plotted on the graphic field in order to visualize the patterns. Subsequently, based on the results of the correlation analysis, a correlation field was constructed where the correlation coefficient is displayed on the 0Y axis, and the subject's level of competitiveness is on the $0 \mathrm{X}$ axis. In the framework of the correlation analysis, the resulting correlation coefficient shows the existence of a relationship between the dependent and independent variables. This coefficient, always denoted by the Latin letter $r$, can take values between -1 and +1 , and if the value is closer to 1 , then this means strong relation, and if it is closer to 0 , then the relation is weak. If the correlation coefficient is negative, this means there is an inverse relationship: the higher is the value of one variable, the lower is the value of the other one. The obtained correlation coefficient is of practical importance and shows the dependence degree of the competitiveness level on the development of the strategic management system.

\section{Results and Discussion}

In this survey, a comparative analysis of the strategic management system in the Russian Federation's regions and federal cities was conducted at the first stage to verify the previously stated hypothesis. The selection of research objects was based on the competitiveness rating of the Russian Federation's regions published by the Leontief Center Consortium - AV Group. Five most competitive regions were taken (Moscow, Tyumen region, Sakhalin region, St. Petersburg, and Sverdlovsk region), four least competitive regions (Republic of Tyva, Karachay-Cherkess Republic, the Republic of Ingushetia and the Chechen Republic) as well as the Republic of Tatarstan, as an object of comparative analysis were chosen.

The cumulative indices for the block "Normative legal acts" for 2008-2016 differ in a very small range of values (four different values depending on a particular situation or year). During all 9 years in all subjects, most often there is a progressive trend (up to 2012), then a regressive trend, which reflects an increase in the number of regulations that contribute to improving the competitiveness of regions, with the exception of the last two years (see Figure 1). 


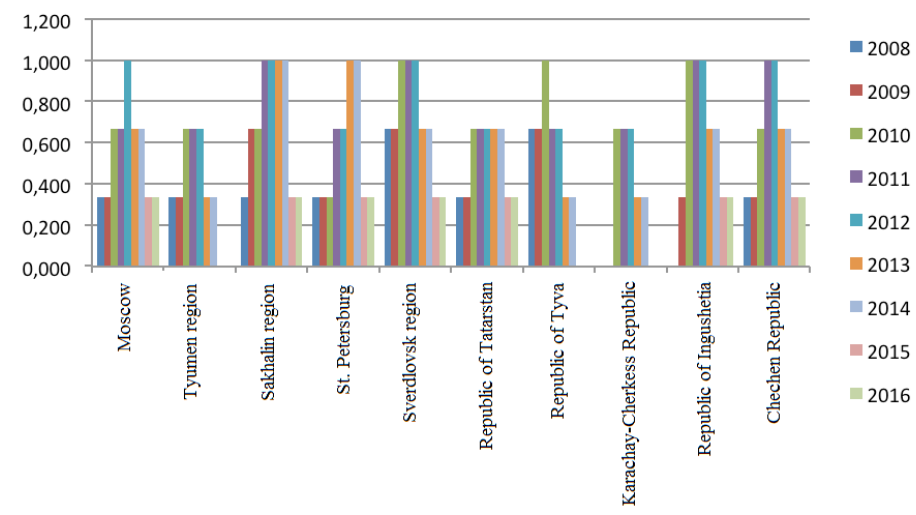

Figure 1. Change dynamics in the cumulative index of regions in the block "Normative legal acts" for 2008-2016

If we consider the results of the cumulative index of this block in the context, we can pay attention to some features of the strategic management system in the analyzed territories. These features primarily consist in the fact that a number of constituent territories have full legal support for the strategic management system, and in some there are not any at all.

Table 1. Availability of a development strategy in region or federal city (0-unavailability, 1-availability of a strategy)

\begin{tabular}{llllllllll}
\hline & 2008 & 2009 & 2010 & 2011 & 2012 & 2013 & 2014 & 2015 & 2016 \\
\hline Moscow & 0 & 0 & 0 & 0 & 1 & 1 & 1 & 1 & 1 \\
\hline Tyumen region & 1 & 1 & 1 & 1 & 1 & 1 & 1 & 1 & 1 \\
\hline Sakhalin region & 0 & 0 & 0 & 1 & 1 & 1 & 1 & 1 & 1 \\
\hline St. Petersburg & 0 & 0 & 0 & 0 & 0 & 1 & 1 & 1 & 1 \\
\hline Sverdlovsk region & 1 & 1 & 1 & 1 & 1 & 1 & 1 & 1 & 1 \\
\hline Republic of Tatarstan & 0 & 0 & 0 & 0 & 0 & 1 & 1 & 1 & 1 \\
\hline Republic of Tyva & 1 & 1 & 1 & 1 & 1 & 1 & 1 & 1 & 1 \\
\hline Karachay-Cherkess Republic & 0 & 0 & 1 & 1 & 1 & 1 & 1 & 1 & 1 \\
\hline Republic of Ingushetia & 0 & 1 & 1 & 1 & 1 & 1 & 1 & 1 & 1 \\
\hline Chechen Republic & 0 & 0 & 0 & 1 & 1 & 1 & 1 & 1 & 1
\end{tabular}

The availability of all three legislative documents (socio-economic development programs, socio-economic development strategies and competition development programs) in Moscow was observed only in 2012, while in the Sverdlovsk region as well as in the Republics of Tuva and Ingushetia, this situation was already seen in 2010. A year later, after "Strategy for Socio-Economic Development until 2025" entered into force, the Sakhalin Oblast and the Chechen Republic joined the ranks of these regions. A relatively weak regulatory framework in the field of increasing competitiveness is seen in the Karachay-Cherkess Republic, which in the first two years of the period did not have any of the considered comprehensive legislative acts.

Table 2. The availability of the socio-economic development program in a region or federal city (0-unavailablity, 1 -availability of a strategy)

\begin{tabular}{llllllllll}
\hline & 2008 & 2009 & 2010 & 2011 & 2012 & 2013 & 2014 & 2015 & 2016 \\
\hline Moscow & 1 & 1 & 1 & 1 & 1 & 1 & 1 & 1 & 1 \\
\hline Tyumen region & 0 & 0 & 0 & 0 & 0 & 0 & 0 & 0 & 0 \\
\hline
\end{tabular}




\begin{tabular}{llllllllll}
\hline Sakhalin region & 1 & 1 & 1 & 1 & 1 & 1 & 1 & 1 & 1 \\
\hline St. Petersburg & 1 & 1 & 1 & 1 & 1 & 1 & 1 & 1 & 1 \\
\hline Sverdlovsk region & 1 & 1 & 1 & 1 & 1 & 1 & 1 & 1 & 1 \\
\hline Republic of Tatarstan & 1 & 1 & 1 & 1 & 1 & 1 & 1 & 1 & 1 \\
\hline Republic of Tyva & 1 & 1 & 1 & 0 & 0 & 0 & 0 & 0 & 0 \\
\hline Karachay-Cherkess Republic & 0 & 0 & 0 & 0 & 0 & 0 & 0 & 0 & 0 \\
\hline Republic of Ingushetia & 0 & 0 & 1 & 1 & 1 & 1 & 1 & 1 & 1 \\
\hline Chechen Republic & 1 & 1 & 1 & 1 & 1 & 1 & 1 & 1 & 1
\end{tabular}

As of 2014, three constituent territories did not have socio-economic development program: the Tyumen region, the Republic of Tuva and the Karachay-Cherkess Republic; at the same time, all constituent territories had socio-economic development strategies. It is important to note that since 2010, almost all entities have implemented competition development programs (since 2011 - all of them), which is primarily due to the need for regional policies to comply with the federal competition development program in the Russian Federation adopted by the Government of the Russian Federation 19 May 2009 for 2009-2012.

Table 3. The availability of a competition development program in a region or federal city (0-unavailability, 1 -availability of a strategy)

\begin{tabular}{llllllllll}
\hline & 2008 & 2009 & 2010 & 2011 & 2012 & 2013 & 2014 & 2015 & 2016 \\
\hline Moscow & 0 & 0 & 1 & 1 & 1 & 0 & 0 & 0 & 0 \\
\hline Tyumen region & 0 & 0 & 1 & 1 & 1 & 0 & 0 & 0 & 0 \\
\hline Sakhalin region & 0 & 1 & 1 & 1 & 1 & 1 & 1 & 1 & 1 \\
\hline St. Petersburg & 0 & 0 & 0 & 1 & 1 & 1 & 1 & 1 & 1 \\
\hline Sverdlovsk region & 0 & 0 & 1 & 1 & 1 & 0 & 0 & 0 & 0 \\
\hline Republic of Tatarstan & 0 & 0 & 1 & 1 & 1 & 0 & 0 & 0 & 0 \\
\hline Republic of Tyva & 0 & 0 & 1 & 1 & 1 & 0 & 0 & 0 & 0 \\
\hline $\begin{array}{l}\text { Karachay-Cherkess } \\
\text { Republic }\end{array}$ & 0 & 0 & 1 & 1 & 1 & 0 & 0 & 0 & 0 \\
\hline Republic of Ingushetia & 0 & 0 & 1 & 1 & 1 & 0 & 0 & 0 & 0 \\
\hline Chechen Republic & 0 & 0 & 1 & 1 & 1 & 0 & 0 & 0 & 0
\end{tabular}

However, after the end of this federal program, similar regional documents ceased to be applied in all entities except two - at the moment, the Sakhalin Oblast is implementing the "Action Program for the Development of Competition in the Sakhalin Oblast for 2009 - 2015", in St. Petersburg - "Competition Development Programs in St. Petersburg for 2011-2015".

At the second stage, the composite cumulative competitiveness index was calculated within the framework of the previously described methodology, which suggests an average of 6 blocks. (See Table 4).

Table 4. Composite Cumulative Competitiveness Index for 2008-2016

\begin{tabular}{llllllllll}
\hline & 2008 & 2009 & 2010 & 2011 & 2012 & 2013 & 2014 & 2015 & 2016 \\
\hline Moscow & 0,646 & 0,645 & 0,682 & 0,721 & 0,742 & 0,683 & 0,741 & 0,731 & 0,724 \\
\hline Tyumen region & 0,366 & 0,336 & 0,375 & 0,345 & 0,325 & 0,332 & 0,335 & 0,327 & 0,325 \\
\hline Sakhalin region & 0,416 & 0,506 & 0,480 & 0,540 & 0,483 & 0,467 & 0,525 & 0,498 & 0,491 \\
\hline St. Petersburg & 0,406 & 0,472 & 0,485 & 0,415 & 0,423 & 0,517 & 0,523 & 0,498 & 0,499 \\
\hline
\end{tabular}




\begin{tabular}{|c|c|c|c|c|c|c|c|c|c|}
\hline Sverdlovsk region & 0,265 & 0,246 & 0,275 & 0,229 & 0,202 & 0,189 & 0,237 & 0,186 & 0,185 \\
\hline $\begin{array}{l}\text { Republic } \\
\text { Tatarstan }\end{array}$ & 0,278 & 0,256 & 0,294 & 0,281 & 0,288 & 0,275 & 0,314 & 0,299 & 0,303 \\
\hline Republic of Tyva & 0,030 & 0,041 & 0,053 & 0,044 & 0,055 & 0,046 & 0,050 & 0,092 & 0,096 \\
\hline $\begin{array}{l}\text { Karachay-Cherkess } \\
\text { Republic }\end{array}$ & 0,068 & 0,053 & 0,046 & 0,122 & 0,115 & 0,109 & 0,115 & 0,141 & 0,146 \\
\hline $\begin{array}{l}\text { Republic } \\
\text { Ingushetia }\end{array}$ & 0,016 & 0,000 & 0,011 & 0,022 & 0,033 & 0,058 & 0,000 & 0,051 & 0,058 \\
\hline Chechen Republic & 0,025 & 0,038 & 0,043 & 0,043 & 0,039 & 0,029 & 0,038 & 0,000 & 0,045 \\
\hline
\end{tabular}

Based on the results obtained, the only region with a relatively high level of competitiveness is Moscow with final index of more than 0.7 over the entire period (with the exception of a slight lag in 2008-2010). Thus, the range of the capital's values varies from 0.645 (2009) to 0.742 (2012), showing a large gap from the rest of the regions. This phenomenon is due to the high level of socio-economic development of the city, high investment and innovation potential, as well as the most powerful potential for business development. The closest competitors of Moscow are the Sakhalin oblast and Saint Petersburg, where the average cumulative index for the entire period is 0.45. At the same time, in Saint Petersburg during the entire period under review, the cumulative index varies from 0.406 to 0.523 , and the Sakhalin oblast has a range of changes in this indicator from 0.416 to 0.540 .

Tyumen region ranks the fourth, followed by the Republic of Tatarstan. Behind them is the Sverdlovsk region, which could well be on a par with the Republic of Tatarstan, if not for the negative trend in the dynamics of the cumulative index, in particular, the dynamics in 2010-2013 and 2014-2016.

If to present the results as a diagram, we can observe a significant gap between the leaders and outsiders.

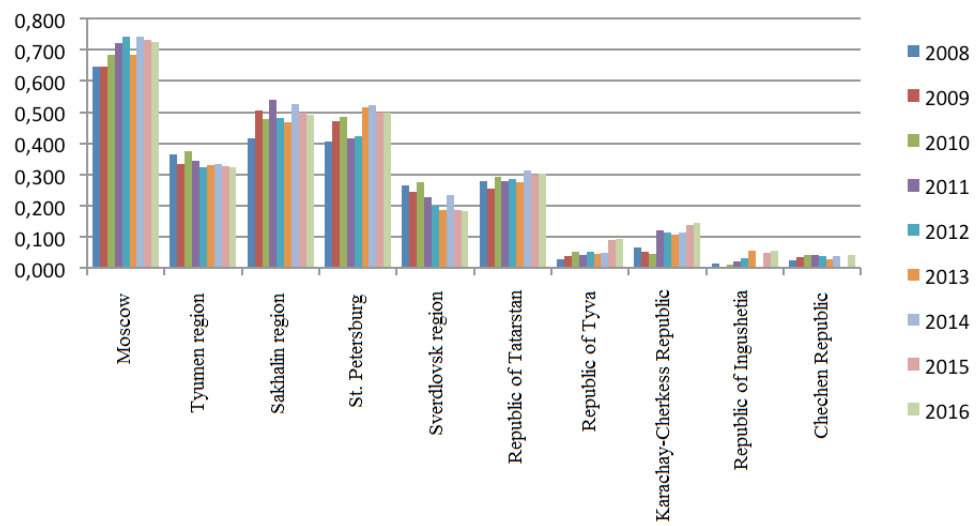

Figure 2. Dynamics in the final cumulative competitiveness index for 2008-2016

Tuva, Karachay-Cherkess Republic, Republic of Ingushetia and the Chechen Republic, in turn, are regions with a low competitiveness level that naturally comes from the fact that all four regions are at the bottom of the competitiveness ranking, based on which constituent territories were selected.

However, it is important to emphasize that this classification is relative, and therefore such a critical situation in the regions under consideration in terms of their competitiveness is largely determined by the large gap between the "reference region" (whose maximum indicators were basis for calculating cumulative indices), this status was occupied by Moscow in most of the analyzed indicators, and the rest of the territories of the Russian Federation.

In the third stage, within the stated hypotheses, the influence of strategic management on the competitiveness level of subjects was analyzed. For this purpose, a correlation field was constructed where the results of the final index of strategic management development are displayed on the $0 \mathrm{Y}$ axis, and the results of the final index of the subject's competitiveness are displayed on the $0 \mathrm{X}$ axis (Figure 3). 


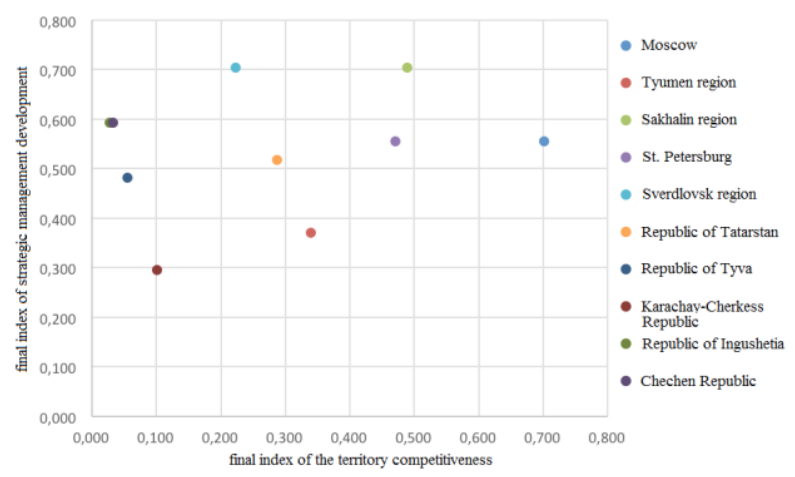

Figure 3. The correlation field of the influence of the strategic management system development on the final index of the territory competitiveness

The points of this correlation field are constructed relative to the averaged values of the previously analyzed final indicators of the development of the strategic planning system and the competitiveness level of the subjects. Based on the obtained figure, it can be concluded that the relationship between the level of development of the strategic planning system and the competitiveness level of the regions and federal cities of the Russian Federation is ambiguous. This conclusion is not common for all entities, as there are exceptions, namely the Chechen Republic, the Republic of Ingushetia and the Sverdlovsk Region. The listed regions have a high final index of strategic management development and a relatively low final index of competitiveness, which point at a number of institutional problems that impede the growth of competitiveness.

To conduct a more detailed analysis of the influence of dependent variables on the independent one, a correlation analysis was carried out, the results of which were also reflected in the correlation field, where the index of the subject's competitiveness is displayed on the $0 \mathrm{X}$ axis, and the degree of dependence of the subject's competitiveness index on the level of strategic management development is shown on the $0 \mathrm{Y}$ axis (Fig. 4). The practical significance of this analysis is to determine the targeted recommendations to improve the development institutions of strategic management in federal cities and regions of the Russian Federation in order to increase their key competitiveness levels.

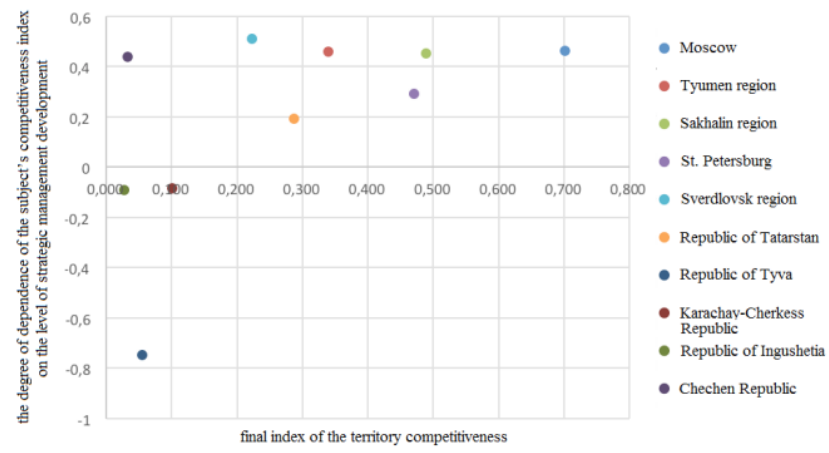

Figure 4. Correlation field of the dependence of the subject competitiveness final index on the correlation coefficient

Given the correlation analysis results, the primary conclusion was proved that there is no unclear character of the dependence. For instance, most subjects do not have a significant statistical relationship between the development level of strategic management and the competitiveness level, since the obtained correlation coefficients range from -0.5 to 0.5 , which demonstrates a weak direct and inverse relationship. In this analysis framework, it was not discovered that the development of strategic management in the constituent territories would increase the competitiveness level since other factors can have the most potent effect on the competitiveness of regions and federal cities of the Russian Federation. 


\section{Summary}

Only partial conclusions can be drawn on two subjects: the Sverdlovsk region and the Republic of Tuva.

The first region has a correlation coefficient of 0.55 , which indicates a relatively strong direct relationship. The practical significance of this indicator suggests that there are prospects for the development of regional competitiveness by improving the strategic process in this region.

As for the Republic of Tuva, there is a reverse situation, which is confirmed by a correlation coefficient of -0.75 , which indicates a strong inverse relationship between the competitiveness level and the strategic management development. The practical significance of this indicator testifies that there are institutional problems that affect of the implementation of the strategic management process in the region, which in turn will not allow to improve the competitiveness level of this subject.

\section{Conclusions}

According to the results of the analysis, the hypothesis about the presence of a direct relationship between the development of the strategic management system and the competitiveness level of the regions and federal cities of the Russian Federation was refuted. In this regard, we can assume that the strategic management process is isolated from the process of competitiveness formation, or has insufficiently significant influence.

\section{Acknowledgements}

The work is performed according to the Russian Government Program of Competitive Growth of Kazan Federal University.

\section{References}

Alexa, D., cismas, L. M., Rus, A. V., \& Pop Silaghi, M. I. (2019). Economic growth, competitiveness and convergence in the European regions. A spatial model estimation. Economic Computation \& Economic Cybernetics Studies \& Research, 53(1).

Capello, R., \& Cerisola, S. (2019). Competitiveness through integration in the European Union Strategy for the Alpine Region: A 'balanced development' approach. European Planning Studies, 27(5), 1013-1034.

Degl'Innocenti, M., Matousek, R., \& Tzeremes, N. G. (2018). Financial centres' competitiveness and economic convergence: Evidence from the European Union regions. Environment and Planning A: Economy and Space, 50(1), 133-156.

Glebova, I. S., Vorobyev, A. A., \& Garipova, G. N. (2015). Analysis and possibilities of increasing of labor potential in the regions of the Volga Federal District (Russian Federation). Mediterranean Journal of Social Sciences, 6(S3), 294-294.

Krasniqi, I. (2019). Strategic management for regional economic development and business sustainability: countries in transition.

Krasniqi, I., \& Statovci, B. (2019). The role of leadership and strategic decision on regional development in developing countries.

Loginov, M. P., Noeva, E. E., Volkovitckaia, G. A., Murinovich, A. A., \& Serebrennikova, A. I. (2018). Competitiveness-based Typology of the Russian Regions. European Research Studies, 21, 787-796.

Petrova, Y. A., Kalinina, V. V., \& Shevandrin, A. V. (2014). Methodological issues and formation principles of effectiveness assessment system of the territory management taking into account strategic development points. Economy of Region/Ekonomika Regiona, 40(4).

Prudskiy, V. G., Demin, G. A., Oshchepkov, A. M., \& Gershanok, A. A. (2017). Modern Russian and foreign approaches to strategic planning of the regional socio-economic development. Journal of Advanced Research in Law and Economics, 8(24), 570-580.

Tazhitdinov, I. A. (2013). The applying stakeholder approach to strategic management of territories development. Economy of Region / Ekonomika Regiona, (2).

\section{Copyrights}

Copyright for this article is retained by the author(s), with first publication rights granted to the journal.

This is an open-access article distributed under the terms and conditions of the Creative Commons Attribution license (http://creativecommons.org/licenses/by/4.0/). 